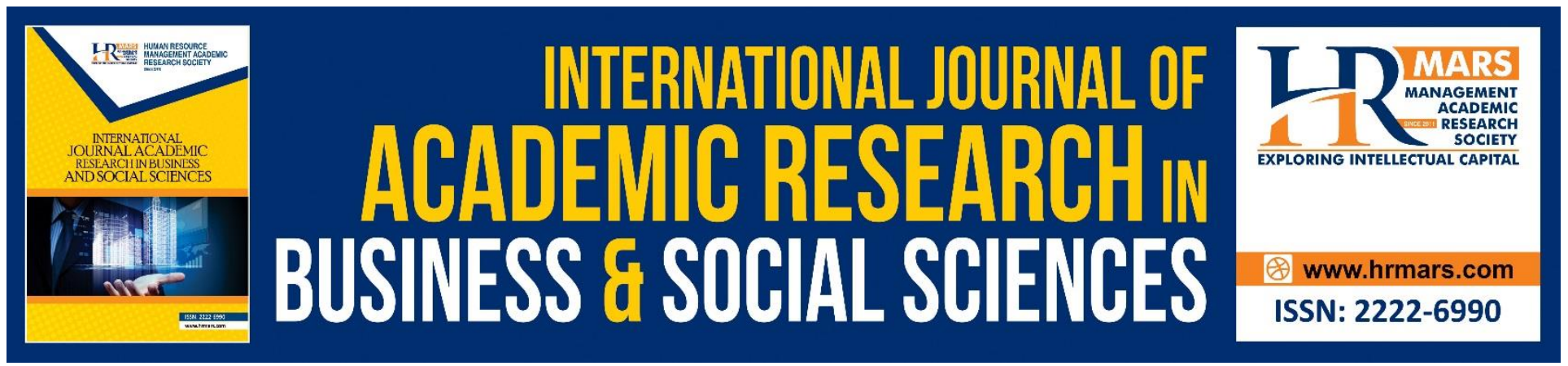

\title{
Ability in Comprehending Meaning of the Quranic Verses among Tahfiz Students
}

Mohamad Marzuqi Abdul Rahim, Abd Hadi Borham, Azmil Hashim, Ibrahim Hashim

To Link this Article: http://dx.doi.org/10.6007/IJARBSS/v8-i11/5338

DOI: $10.6007 /$ IJARBSS/v8-i11/5338

Received: 24 Oct 2018, Revised: 13 Nov 2018, Accepted: 30 Nov 2018

Published Online: 03 Dec 2018

In-Text Citation: (Rahim, Borham, Hashim, \& Hashim, 2018)

To Cite this Article: Rahim, M. M. A., Borham, A. H., Hashim, A., \& Hashim, I. (2018). Ability in Comprehending Meaning of the Quranic Verses among Tahfiz Students. International Journal of Academic Research in Business and Social Sciences, 8(11), 1646-1656.

\section{Copyright: (c) 2018 The Author(s)}

Published by Human Resource Management Academic Research Society (www.hrmars.com)

This article is published under the Creative Commons Attribution (CC BY 4.0) license. Anyone may reproduce, distribute, translate and create derivative works of this article (for both commercial and non-commercial purposes), subject to full attribution to the original publication and authors. The full terms of this license may be seen at: http://creativecommons.org/licences/by/4.0/legalcode

Vol. 8, No. 11, 2018, Pg. 1646 - 1656

Full Terms \& Conditions of access and use can be found at http://hrmars.com/index.php/pages/detail/publication-ethics 


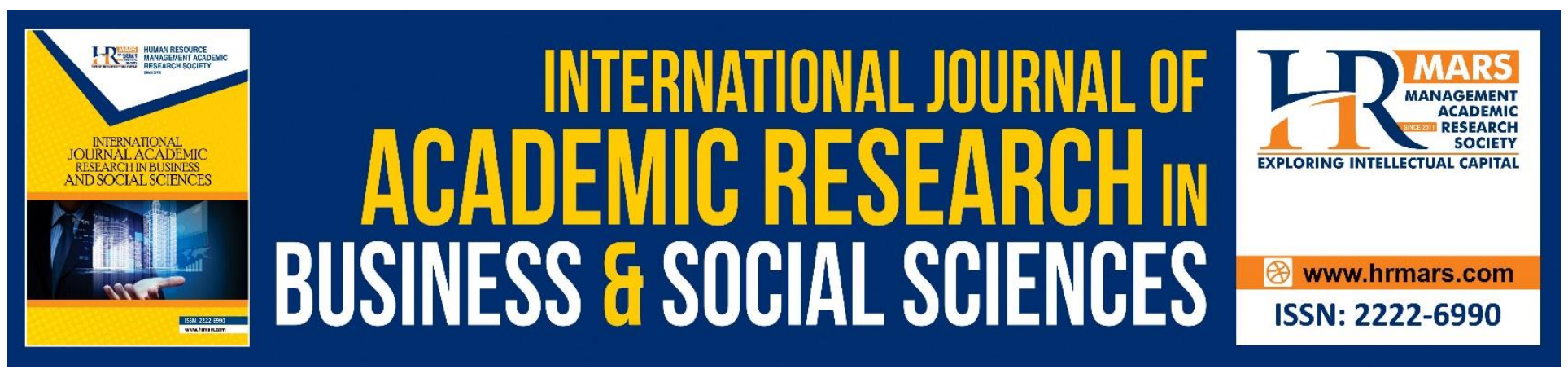

\title{
Ability in Comprehending Meaning of the Quranic Verses among Tahfiz Students
}

\author{
Mohamad Marzuqi Abdul Rahim, Abd Hadi Borham, Azmil Hashim, \\ Ibrahim Hashim \\ Universiti Pendidikan Sultan Idris (UPSI), Malaysia
}

\begin{abstract}
This study was conducted to examine tahfiz students' ability in comprehending the word meaning, theme and translation of verses of the Qur'an before commencing in the process of memorizing Qur'an. The survey was conducted on 80 school leavers who were randomly selected for this research. There are 25 multiple choice questions and 5 subjective questions in the questionnaires. Data were collected and analyzed in percentage and mean scores using SPSS 20.0 software. The results showed that majority of students cannot answer questions properly pertaining the translation of verses of theQur'an provided. Thus, a module was proposed for tahfiz students in order to develop comprehension skills on verses of the Qur'an that are being memorized.

Keywords: Tahfiz al-Qur'an, Student Ability, Comprehending Skill, Qur'an Translation.

\section{Introduction}

Al-Qur'an is a miracle of the Prophet PBUH (peace be upon him) that exists till the end of time. Although the Qur'an was revealed in Arabic and must be read in Arabic, it is incumbent upon every Muslim to understand meaning of the verses he reads, even though he is not an Arab, because the Qur'an is a guidance to all Muslims, as saying of Allah Almighty:

Meaning: This is the Scripture where of there is no doubt, a guidance unto those who ward off (evil).
\end{abstract}

(Surah al-Baqarah 2:2)

This verse is a clear signal that Qur'an is not only revealed by Allah as a mere recital book, instead it is guidance in life. When mentioning guidance, it encompasses various aspects. At the end of this verse Allah says, "a guidance unto those who ward off (evil)", i.e. those who fear Allah Almighty. 
INTERNATIONAL JOURNAL OF ACADEMIC RESEARCH IN BUSINESS AND SOCIAL SCIENCES

Vol. 8, No. 11, Nov, 2018, E-ISSN: 2222-6990 @ 2018 HRMARS

In addition there are many words of Allah which encourage human to understand, observe and ponder the meaning of the verses of Qur'an, this include:

Meaning: Will they not then ponder on the Qur'an? If it had been from other than Allah they would have found therein much incongruity.

(Surah al-Nisa' 4:82)

Meaning: (This is) a Scripture that We have revealed unto thee, full of blessing, that they may ponder its revelations, and that men of understanding may reflect.

(Surah Sad 38:29)

Meanwhile Allah Almighty also urged those who listen to recitatation of the Qur'an to keep queit and ponder its meaning as the Allah says:

Meaning: And when the Qur'an is recited, give ear to it and pay heed, that ye may obtain mercy.

(Surah al-A'raf 7:204)

Al-Nawawi (1984) stated that manners for those who reads the Qur'an should be in khusyu' (concentrate) and tadabbur (ponder) the meaning of verses of the Qur'an that were read. AlAqrabawi (1991) also pointed out that someone who wants to speak with his Lord, must read the Qur'an by presenting God's greatness in one hearts. While al-Syatibi rahimahullah (May Allah has mercy on him) said in his syair (poetry) as-Syatibiyyah that al-Qur'an is a book that does not make one bored when reading it, as a matter of fact it adds glory to the Qur'an when one observed repeatedly while pondering its meaning respectively.

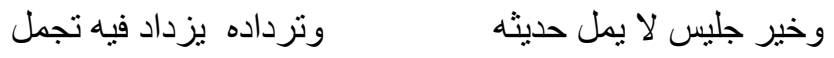

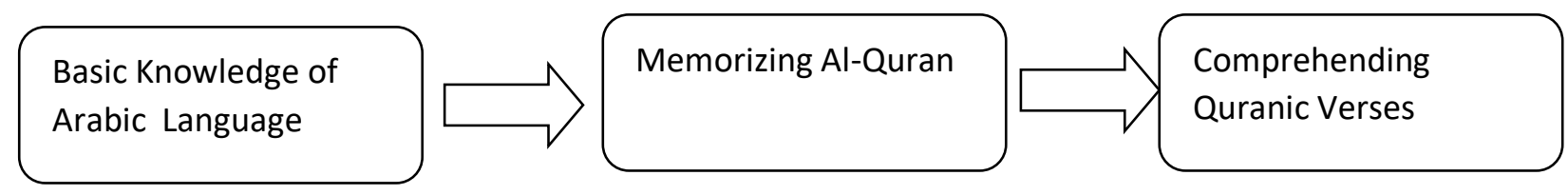

Figure 1: The Process of comprehending al-Quran in memorizing Al-Quran

Al-Qur'an is a holy and highly valued book which manages to produce successful and glorious civilization of Muslims of different races because it continuously guide Muslims in understanding and internalising the religion, then they applied in their livelihood (Anwar, 2015). Although Islam is a religion to many non-Arabs, it does not mean non-Arabs cannot understand the Qur'an. It has been translated into 130 other languages as an approach for non-Arabs in comprehending its contents. 
As a non-Arab nation, the Malaysian government through the Ministry of Education has prepared an integrated curriculum in order to produce young Muslims who can understand and internalise the religion of Islam. This curriculum of Islamic education through KBSM is divided into three main areas i.e. learning recitation of al-Qur'an and Hadith, learning Ulum Syariah and Akhlak Islamiah (Islamic Etiquette). Al-Qur'an and Hadith area has the most allocated time i.e. three (3) periods per week in contrast to other areas of learning. The main focus of al-Qur'an and Hadith is to comprehend the meaning and wisdom of verses of the Qur'an, and selected Hadith.

Based on Sijil Pelajaran Malaysia or SPM (Malaysian Certificate of Education or MCE) results, Darul Quran JAKIM has set eligibility requirements for Diploma in Tahfiz Al-Qur'an program, is a credit in either subject; Qur'an and Sunnah subject or Syariah subject. It also requires a credit in Arabic Language in Sijil Pelajaran Malaysia (Darul Quran, 2017). After going through interview, qualified and top ranking candidates will be offered a course in Diploma in Tahfiz Al-Qur'an for three years or six semesters.

\section{Research Background}

Teaching and learning tahfiz al-Qur'an course at Darul Quran require students to be able to memorize the whole Qur'an 30 juz (chapters) in order to be awarded Diploma in Tahfiz Al-Qur'an by JAKIM. Nevertheless, the main goal of tahfiz al-Qur'an program is not only to produce capable students that can recite and memorize the Qur'an well, but essentially is to produce du'at (preacher), educators and trained professionals imam through study in sciences of the Qur'an (Darul Quran, 2007). This product is a human capital that can contribute to society and country. This goal will be irrelevant if these tahfiz leavers cannot master in understanding the meaning of Qur'an verses holistically.

Time allocated for teaching and learning of al-Qur'an is 2 hours per day, where compulsory activities such as Talaqi Qur'an (teachers correct students' recitation), tasmi' al-Qur'an (teachers listen and record students' memorization) and ia'dah (teachers evaluate student memorization mastery through replicates). A tahfiz class typically has 10 to 15 students (Darul Quran, 2003). Logically, a teacher will focus on these three activities concurrently between 10 to 12 minutes for each student. Therefore this implies that teachers have limited time and cannot assist students in comprehending the meaning of verses of the Qur'an in a tahfiz (memorization) lesson.

In addition, a study was conducted in December 2007 and it was found that $65.6 \%$ of 212 students at Darul Quran whom were samples of the research, mentioned the lecturers did not guide in comprehending the meaning of verses of Qur'an during lesson (Marzuqi, 2008). Only 34.4\% of students who agreed with the statement that mentioned lecturers guide in understanding the meaning of verses of the Qur'an during class. This shows technical comprehending in the meaning of Qur'an verses is less emphasis during hafazan (memorization) al-Qur'an teaching.

Misnan and Ahmad Sadadi (2003) also stressed on factor that most students are weak in memorizing the Qur'an is due to lack in comprehending the translation and meaning of verses of the Qur'an that are being memorized. This shows that comprehending the meaning of verses of the 
Qur'an is related to students' memorization (level). As such the author compelled to carry out this study to determine the ability of students attended Darul Quran and their comprehending in meaning of verses of the Qur'an before they begin tutoring sessions in memorization of the Qur'an.

In addition, it has been identified that there are a number of writing and scientific studies related to this research. Among the study is by Farhana \& Munirah (2015) which was conducted to investigate the effectiveness of two teaching modules by Arabic languague practitioners in understanding verses of the Qur'an. The study found that both modules i.e. learn Arabic using Qur'anic word by word and al-Furqan Arabic education have their own approach and strength. It is suggested that comprehending of verses of the Qur'an be included in Islamic education subject at lower secondary level.

Studies by (Misnan, 2006) in a few secondary schools of Ministry of Education Malaysia in Perak showed that teaching on comprehension of verses of the Qur'an is moderate and low level with the mean of 2.94. Thus, teaching on comprehending of verses of the Qur'an need a proper strategy and planning from the teacher so this lesson can draw students' attention and their comprehension will improve. The study also showed students master in recitation of the Qur'an from various resources such as their parents, Qur'an teachers, religious schools and others. But mastering in translation and interpretation of verses of the Qur'an is the outcome of primary and secondary school education besides attending religious schools in the evening.

Action research conducted by Marzuqi (2008) to 12 students who have memorized the Qur'an from a tahfiz Qur'an class, also showed that some students did not understand the meaning of verses of Qur'an that have been memorized whilst $25 \%$ of students scored less than $40 \%$ in a test on comprehension the meaning of words of al-Qur'an. The results of interviews with students who score low, found that they did not refer to the translation before or after the process of memorizing the Qur'an.

Anwar (2015) stated that comprehending the contents of the Qur'an is more challenging for Muslims who do not master the Arabic language. Therefore it requires a special method in order to understand verses of the Qur'an that are being read. To overcome this shortcoming, translation is an important methods solution. Al-Qur'an which has been translated into 130 languages ethnic groups in the world was assists the non speaking Arabic Muslims in comprehend the content of the Qur'an in their native language.

This study is essential since its findings can assist lecturers in preparing better teaching approach that is appropriate to Qur'an memorization lesson. A test on comprehension the meaning of verses of the Qur'an may be apply in order to determine level of existing knowledge among students before commencing in a teaching and learning process. In Qur'an memorization lessons, lecturers should apply teaching methods that can stimulate students learning curiosity, such as using variety of teaching techniques and strategies so as to achieve objectives in understanding the meaning of verses of the the Qur'an. 
Finding from this study may also have interests to administration of religious institutions, especially Darul Quran JAKIM which aims to improve performance of lecturers and students. This effort is to produce students who are not only proficient in reading and memorizing the Qur'an as well as internalised the Qur'an in everyday life.

\section{Research Objectives}

The aim of this study is to investigate comprehension in meaning of the Qur'an level of MCE students' leaver who will follow Diploma in Tahfiz Al-Qur'an program.

\section{Research Questions}

i. What is the level of comprehension of the meaning of the Qur'an verses for Diploma in Tahfiz AlQur'an program candidates?

ii. Is there any significant differences in average mean score in comprehension verses of the Qur'an between male and female students?

iii. Is there a correlation between academic qualifications (Arabic languague) during interview with student scores in Al-Qur'an comprehension test?

\section{Research Methodology}

This study is a quantitative research using survey method to obtain information on students' comprehension of verses of the Qur'an to be memorized, as well as the relationship between students' academic credentials (Arabic Language in MCE) and their score in meaning of verses of the Qur'an comprehension test. In order to answer the research questions, researcher will analyze the data obtained by descriptive and inferrence statistics. A set of written comprehension tests on meaning of verses of the Qur'an was constructed, for the purpose of collecting data from respondents who were chosen randomly.

The population is 224 new students who have attended at Darul Quran for Diploma in Tahfiz AlQur'an program. The samples consist of 80 students who were randomly selected from a list of new students received from intake and record department of Darul Quran JAKIM.

The instrument used in this study is a set of test on comprehension of the meaning of the Qur'an verses which consists of 25 multiple choice questions with four possible answers ( $A, B, C$ and $D)$ on section pertaining to words and themes and five (5) subjective questions on section pertaining to translating verses of al-Qur'an. The items were constructed based on first semester of hafazan (memorization) al-Qur'an syllabus. In order to validate of the contents, researcher has to construct items in this survey based on the table of specifications (TOS) according to Bloom's Taxonomy hierachy. Researcher also referred to a number of experienced lecturers in teaching and learning memorization of the Qur'an as to obtain their views and comments to further enhance validity of the contents. Based on these expert lecturers' reviews, researcher had admend and replaced some of 
INTERNATIONAL JOURNAL OF ACADEMIC RESEARCH IN BUSINESS AND SOCIAL SCIENCES

Vol. 8, No. 11, Nov, 2018, E-ISSN: 2222-6990 (C) 2018 HRMARS

the items that were not appropriate. The test was administered among samples before the first Tasmi' lesson began.

\section{Findings}

\section{Comprehension Level on the Meaning of the Qur'an Verses}

Table 1 below shows an overall level of students' comprehending of verses of the Qur'an. A written comprehension test is carried out and the result is moderate i.e. mean score is 2.35 . In words section, students score is the highest with mean score of 2.83, followed by theme of verses of the Qur'an section with mean score of $2.76 \mathrm{~min}$. Whilst, score on translation of verses section is extremely low, i.e. mean score of 1.40 .

TABLE 1. Mean Scores and Standard Deviation of Comprehension Test on the Meaning of the Qur'an Verses

\begin{tabular}{llccl}
\hline No & Test Item Section & Mean & S.D & Level \\
\hline 1 & Word & 2.83 & 0.44 & High \\
2 & Theme of verses & 2.76 & 0.48 & High \\
3 & Translation of verses & 1.40 & 0.61 & Low \\
& Total of Comprehension Test & 2.35 & 0.59 & Moderate \\
\hline
\end{tabular}

Referring to Table 2, it shows students' scores in objective test on meaning of word in the Qur'an. The findings indicated that the majority of students scored high or excellent (16-20 points), i.e. a total of 68 students or $85 \%$ out of a total samples. Some students get a moderate score (11-15 marks), i.e. a total of 10 students or $12.5 \%$ out of a total samples. Only two students get a low score (0-10 points), i.e. $2.5 \%$ out of a total samples.

TABLE 2. Students' Scores for Comprehension Test on the Meaning of Words of the Qur'an Section

\begin{tabular}{llll}
\hline No & Answer Categories & Frequency & Percentage \\
\hline 1 & Low score $(0-10)$ & 2 & $2.5 \%$ \\
2 & Moderate score (11-15) & 10 & $12.5 \%$ \\
3 & Excellent score (16-20) & 68 & $85.0 \%$ \\
& Total & 80 & $100.0 \%$ \\
\hline
\end{tabular}

Meanwhile, Table 3 below shows students' scores in objective test on verses from the Qur'an theme section. Majority of students scored high or excellent (4-5 marks), i.e. a total of 63 students or $78.8 \%$ out of total samples. Some students get moderate score ( 3 marks) i.e. a total of 15 students or $18.8 \%$ out of total samples. Only 2 students scored low (0-2 marks), i.e. $2.5 \%$ out of total samples. 
INTERNATIONAL JOURNAL OF ACADEMIC RESEARCH IN BUSINESS AND SOCIAL SCIENCES

Vol. 8, No. 11, Nov, 2018, E-ISSN: 2222-6990 @ 2018 HRMARS

TABLE 3. Students' Scores for Comprehension Test on the Theme of the Qur'an Verses Section

\begin{tabular}{llll}
\hline No & Answer Categories & Frequency & Percentage \\
\hline 1 & Low score (0-2) & 2 & $2.5 \%$ \\
2 & Moderate score (3) & 15 & $18.8 \%$ \\
3 & Excellent score (4-5) & 63 & $78.8 \%$ \\
& Total & 80 & $100.0 \%$ \\
\hline
\end{tabular}

Table 4 shows students' score in subjective test in translation of verses of the Qur'an section. Majority of students scored low (0-5 marks), i.e. a total of 53 students or $66.3 \%$ out of total sample. Some students get moderate score (6-7marks) i.e. a total of 22 students or $27.5 \%$ out of total sample. Only 5 people scored high or excellent (8-10 marks) or $6.3 \%$ out of total sample.

Table 4. Students' scores in Comprehension Test on the Translation of the Qur'an Verses Section

\begin{tabular}{clcc}
\hline No & \multicolumn{1}{c}{ Answer Categories } & Frequency & Percentage \\
\hline 1 & Low score (0-5) & 53 & $66.3 \%$ \\
2 & Moderate score (6-7) & 22 & $27.5 \%$ \\
3 & Excellent score (8-10) & 5 & $6.3 \%$ \\
& Total & 80 & $100.0 \%$ \\
\hline
\end{tabular}

\section{Comprehension Level of Male and Female Students}

To verify differences in scores between male and female students, an independent T-tests sample was carried out. Table 5 below explains the differences. The test results showed that scores of male and female students has no significant difference as $p>0.05$. Average mean score for male students is 26.08 , differ only by 0.4 , and average mean score for female students are 25.68 .

TABLE 5. Independent T-test sample between male and female students on mean scores in comprehension test on the meaning of the Qur'an verses

\begin{tabular}{llll}
\hline Students & $\mathrm{N}$ & Min & S.D \\
\hline Male & 40 & 26.08 & 3.996 \\
Female & 40 & 25.68 & 4.974 \\
\hline
\end{tabular}

T-test for Equality of Means 
INTERNATIONAL JOURNAL OF ACADEMIC RESEARCH IN BUSINESS AND SOCIAL SCIENCES

Vol. 8, No. 11, Nov, 2018, E-ISSN: 2222-6990 @ 2018 HRMARS

\begin{tabular}{lllll}
$\mathrm{t}$ & Df & Sig. (2-tailed) & Mean Difference & $\begin{array}{l}\text { Std. Error } \\
\text { Difference }\end{array}$ \\
\hline .397 & 78 & .693 & .400 & 1.009 \\
\hline
\end{tabular}

\section{Relationship between Previous Knowledge in Arabic Language and Comprehension Test of the Qur'an Verses}

To verify whether knowledge of Arabic language based on MCE result is related or not to students' score in comprehension test in this study, the Pearson correlation test was carried out. Referring to Table 6, it shows that the test results in Arabic language knowledge in MCE has a weak or low correlation and no significant effect on students' score in comprehension test of the Qur'an verses.

\section{TABLE 6. Correlation test between MCE Arabic Language Grades with Written Test Comprehension of the Qur'an Verses}

\begin{tabular}{llc}
\hline & \multicolumn{2}{c}{ Written Test Comprehension } \\
\hline MCE Arabic Language Grades & Pearson Correlation & .216 \\
& Sig. (2-tailed) & .055 \\
\hline
\end{tabular}

$\mathrm{N}=80$

\section{Discussion And Conclusion}

In this study, the level of students' comprehension of the Qur'an verses is moderate. It is found that students were able to give meaning of words and state theme of some of the Qur'an verses. But when they were requested to translate the Qur'an verses, the majority of the students were unable to translate verses of the Qur'an into Malay language. This showed that students could not translate verses of the Qur'an properly, which could affect on their comprehending of the Qur'an verses that were read. The level of comprehending verses of the Qur'an among secondary school students is moderate which is also supported by Misnan (2006). Therefore tahfiz educational institution should provide a module that could help students to improve their skills in translating verses of the Qur'an during hafazan (memorization) lessons.

Hafazan lesson should not stop at talaqqi and tasmi only, instead an emphasis should be put on comprehending the meaning of the Qur'an verses as claimed by the al-Qur'an (al-Nisa: 82; al-Sad: 29; al-A'raf: 204). As well as recommendations from scholars (al-Nawawi, 1984; al-Syatibi, 1990; alAqrabawi, 1991) so as to focus on tadabbur (ponder) of the Qur'an. Emphasis on comprehension the meaning of the Qur'an verses will also help strengthen hafazan (memorization) as specified by Misnan and Sadadi (2003) that most students are weak in memorization due to lack in comprehending in translation and meaning of verses of the Qur'an that they memorized.

In terms of comprehending the meaning of the Qur'an verses pattern between male and female students, the difference is insignificant. Their level on comprehending the Qur' an is moderate. This indicates that gender differences do not affect students' comprehension of the Qur'an verses. 
Thus, this allows management of al-Qur'an tahfiz institutions to develop the appropriate teaching and learning strategies to students regardless of gender.

Students who attended in Darul Quran and most government hafazan (memorization) institutions are required to get credit level for Arabic Language subject. This eligibility requirement is to ensure that students can follow the curriculum of memorization al-Qur'an which mainly using Arabic Language as medium of teaching. This study show there is a weak correlation and non significant effect between previous knowledge in Arabic Language and the scores in comprehension test of the Qur'an verses. This is due to students are only confident to translate only specific words of the Qur'an and are not able to translate the verses thoroughly. It is reasonable for tahfiz institutions to empower Arabic language among students, which is cross-curricular natured and as suggested by Farhana and Munirah (2015), i.e. drafting of Arabic language syllabus specifically to comprehending the Qur'an. Apart from, admission qualification for students should be re-evaluated by tahfiz al-Qur'an education authority.

\section{Acknowledgements}

This research was supported by RMIC Sultan Idris Education University under research grant GPU 2017-0288-107-01. We thank our colleagues from Department of Islamic Studies, Faculty of Human Science UPSI who provided insight and expertise that greatly assisted the research

\section{Corresponding Author}

Name: Mohamad Marzuqi Abdul Rahim (Corresponding Author)

Affiliation: Universiti Pendidikan Sultan Idris (UPSI)

E-mail: marzuqi@fsk.upsi.edu.my

\section{References}

Al-Qur'an al-Karim.

Abdullah, M. B. (1998). Tafsir pimpinan ar-Rahman. Kuala Lumpur: Bahagian Hal Ehwal Islam Jabatan Perdana Menteri.

Al-Aqrabawi, Z. M. (1991). Al-Mursyid fi ilmi al-Tajwid. Amman Jordan: Darul al-Furqan.

Al-Nawawi, Y. S. (1984). Al-Tibyan fi adabi hamalatil Qur'an. Beirut: Dar an-Nafais

Al-Syatibi, A. M. (1990). Hirzul amani wa wajhu at-tahani. Al-Madinah Al-Munawwarah: Dar alMatbu'ah al-hadithah.

Anwar, R. (2015, April 29). Penterjemahan Al-Qur'an bantu kemajuan ummah. Berita Harian.

Anwar, R. (2015, Julai 6) Terjemahan al-Qur'an mesti dipelihara elak diseleweng. Berita Harian. 
INTERNATIONAL JOURNAL OF ACADEMIC RESEARCH IN BUSINESS AND SOCIAL SCIENCES

Vol. 8, No. 11, Nov, 2018, E-ISSN: 2222-6990 @ 2018 HRMARS

Darul Quran. (2003). Kertas permohonan penggredan dan pensturkturan semula perjawatan Darul Quran JAKIM.

Darul Quran (2007). MS ISO 9001: 2000 Darul Quran Jabatan Kemajuan Islam Malaysia. Penerbitan Darul Quran JAKIM.

Darul Quran. (2017). Program diploma tahfiz al-Qur'an. Retrieved July 25, 2017, from http://www.darulQur'an.gov.my/.

Farhana, I. \& Munirah, A. (2015). Keberkesanan pengajaran bahasa Arab untuk pemahaman ayat alQur'an. E-Proceeding of the International Conference on Social Science Research, ICSSR 2015.

Gamal, A. N. (2003). Ibnu Shahnun, Al-Qabisi, Ibnu Khaldun Prinsip-Prinsip Pendidikan Islam. Bentong, Pahang: PTS Publication.

Irfan, M. (2008, Ogos 29). Membina generasi ambil berat al-Qur'an. Utusan Malaysia.

Misnan, J. (2006). Metodologi pengajaran al-Qur'an sekolah menengah. Kajian Cuti Sabatikal: Fakulti Sains Kemanusiaan, UPSI Tanjung Malim.

Misnan, J \& Ahmad, S. H. (2003). Hubungan antara kaedah menghafaz al-Qur'an dengan pencapaian kursus tahfiz wa al-Qiraat pelajar semester empat dan lima di Maahad Tahfiz wa al-Qiraat di Perak. Nilai: KUIM.

Marzuqi, A. R. (2008). Pengajaran mata pelajaran hafazan al-Qur'an: suatu kajian maahad tahfiz alQur'an zon tengah. Laporan Projek Sarjana, Fakulti Sains Kognitif dan Pembangunan Manusia: Universiti Pendidikan Sultan Idris.

Marzuqi, A. R. (2008). Kajian tindakan pengajaran kelas tahfiz al-Qur'an. Darul Quran JAKIM.

Marzuqi, A. R. (2008). Kaedah memahami terjemahan ayat al-Qur'an sewaktu kelas hafazan: suatu keperluan. Jurnal Darul Quran, 12, hlm 25-35. 